\title{
Lumen
}

Selected Proceedings from the Canadian Society for Eighteenth-Century Studies

\section{Dialogues on the Events at Québec 1759: Lucianic Satire, Excuses and Propaganda}

\section{David McNeil}

Volume 30, 2011

URI : https://id.erudit.org/iderudit/1007715ar

DOI : https://doi.org/10.7202/1007715ar

Aller au sommaire du numéro

Éditeur(s)

Canadian Society for Eighteenth-Century Studies / Société canadienne d'étude du dix-huitième siècle

ISSN

1209-3696 (imprimé)

1927-8284 (numérique)

Découvrir la revue

Citer cet article

McNeil, D. (2011). Dialogues on the Events at Québec 1759: Lucianic Satire, Excuses and Propaganda. Lumen, 30, 45-59. https://doi.org/10.7202/1007715ar

Copyright (c) Canadian Society for Eighteenth-Century Studies / Sociéte canadienne d'étude du dix-huitième siècle, 2011
Ce document est protégé par la loi sur le droit d'auteur. L'utilisation des services d'Érudit (y compris la reproduction) est assujettie à sa politique d'utilisation que vous pouvez consulter en ligne.

https://apropos.erudit.org/fr/usagers/politique-dutilisation/ 


\section{Dialogues on the Events at Québec 1759: Lucianic Satire, Excuses and Propaganda}

[Bougainville] You Canadians live in a cruel country ... and certainly an uncomfortable one. ... what a setting for regrets and fond desires.

[LaPierre] But you learned something? Something important?

[Bougainville] Yes, I learned something: that I could stand almost anything. The vastness, the ruggedness of the land, and the hardships it exacted may have ruined my health but I was exhilarated. ${ }^{1}$

The foregoing conversation between Montcalm's aide-de-camp LouisAntonie de Bougainville and the modern-day chronicler and one-time media personality Laurier LaPierre is taken from the latter's imaginative history of the events at Québec in 1759. While LaPierre does not associate his method of examining the British siege of the town with Lucian's form, his fictional dialogues between himself and a variety of historical characters at the siege are remarkably similar to those of Lucian and his imitators. One can see these fantastic scenes as LaPierre's attempt to connect emotionally with 1759 as he says in his introduction, "I am a part of 1759. The happenings of that year place me where I am in the world; they define me and compel my spirit and my energies." ${ }^{2}$

The purpose of this essay is to elucidate two rather obscure eighteenth-century dialogues about the events of 1759 that bear Lucianic fea-

1 Laurier L.LaPierre, 1759: A Battle for Canada (Toronto: McClelland \& Stewart, 1990), 63.

2 LaPierre, xiii. 
tures but are politically motivated. While it is the tendency of Lucianic dialogues to take a very wide view of historical events - the distance between the participants leading to a commentary involving general principles and observations - these two "dialogues of the dead" stand out for their pronounced political elements that reveal them to be propagandistic or exculpatory texts. Alan McNairn's study of James Wolfe, Behold the Hero, begins with a description of the first text, A Dialogue betwixt General Wolfe, and the Marquis Montcalm, in the Elysian Fields. Despite McNairn's claim that the dialogue is by "an enterprising English journalist, ${ }^{\prime 3}$ the author remains a mystery. The second text examined here is by the Jacobite Chevalier de Johnstone (James Johnstone) who escaped to France after the ' 45 and served under Montcalm at the siege of Quebec. His contribution to the Menippean genre is subtitled, An Impartial and Military Examination of that Campaign, to Serve as Justification of M. the Marquis of Montcalm. I have two objectives in this essay: one, to situate these dialogues in the context of the tradition going back to Lucian (something that neither McNairn nor the translators/editors of Johnston's text do); and two, to identify their unique features. I conclude that both dialogues are propagandistic and as such have usurped the dialogue form for political ends.

I have used the descriptor "Lucianic" to avoid the problematic term "Menippean satire," which has been addressed by Howard Weinbrot. What characterizes Lucian's dialogues as satires are their sense of philosophical fun that derives precisely from the fictional exchanges of real, yet deceased, human figures, who are imagined to have a kind of informal conversation across the fence of centuries. Lucian himself used two kinds of fictional characters: the dead and the gods. Erasmus practised the form for pedagogical purposes in his Colloquies. Among French writers, one can find dialogues written by Fontenelle, Noveau dialogues des morts (1683), and Fénelon, Dialogues des morts (1700), both of which were translated into English and went through a number of editions. English practitioners include Matthew Prior, Henry Fielding, Lord (George) Lyttelton, Elizabeth Montagu and others. The most important of the latter would have to be Lord Lyttelton, whose Dialogues of the Dead went into five editions between 1760 and 1768 (the first of which appeared a few months after the Wolfe/Moncalm text appeared). In

3 Alan McNairn, Behold the Hero: General Wolfe and the Arts in the Eighteenth Century (Montreal: McGill-Queen's UP, 1997), 3.

4 See Howard D. Weinbrot, Menippean Satire Reconsidered: From Antiquity to Eighteenth Century (Baltimore: The Johns Hopkins University Press, 2005). 
the "Preface," Lyttelton acknowledges Lucian and Fénelon but passes over the contributions of Prior and, Lyttelton's own friend, Fielding so that he may conclude "no Englishman [has] distinguished himself in dialogues of the dead. ${ }^{\prime \prime}$ In more recent times, besides Laurier Lapierre, Steve Allen (who developed the "talk show" for television) used this dialogue format in The Meeting of Minds (PBS 1977-81). ${ }^{6}$ Suffice to say, the satiric form has reappeared in various guises and media in Western culture.

Elsewhere I have written on the military dialogue, a kind of subgenre of the literary form. ${ }^{7}$ One can identify two kinds of military dialogues: first, the exchange can feature two military commanders, normally not historical adversaries (Adolf Hitler and Attila the Hun, for instance) who engage as braggart soldiers dueling for pre-eminence. The second kind features a military commander and a non-military personage, often a philosopher or historian; these tend to be more reflective on the horrors of war. Both make use of comic deflation and the fantastic setting of the Elysian Fields or the world of the dead, the outcome is often a meditation on the vanity of human wishes, especially in those dialogues having to do with fame or reputation.

The general characteristics and history of the dialogue form in English literature have been studied by Fred Keener and Elizabeth Merrill. ${ }^{8}$ Keener's work consists of a commentary, an anthology of seminal examples of the genre going back to Lucian, and a checklist of original English examples of the genre published between 1641 and 1907. The checklist includes the dialogue between Wolfe and Montcalm, which is the only listing for $1759 .{ }^{9}$ No speculations are offered on who the author might be. The only comment that Keener makes about the text concerns its questionable historical claims. Merrill's work dates back to the early twentieth century; she categorizes dialogues as either polemi-

5 Baron George Lyttelton, Dialogues of the Dead (London: 1760), iii.

6 Allen, Steve. Meeting of the Minds, PBS (Jan. 1977 - May 1981). TV.com. July 7, 2011 <http://www.tv.com/meeting-of-minds/show/8461/summary.html>.

7 See David McNeil, "'Dialogues on Military Affairs" in Compendious Conversations: The Method of Dialogue in the Early Enlightenment, ed. Kevin Cope (New York: Peter Lang, 1992), 129-38.

8 Frederick M. Keener, English Dialogues of the Dead: A Critical History, An Anthology, and A Check List (New York: Columbia University Press, 1973) and Merrill, Elizabeth, The Dialogue in English Literature (New York: Archon Books, 1969; rpt, Yale; 1911).

9 Keener, 284. 
cal, expository or philosophical. Her categories overlap, however, to an extent that makes it pointless to try to squeeze an example into one of these groups, and hence, it may be better to examine the Wolfe/Montcalm text in detail.

While A Dialogue betwixt Wolfe and Montcalm, in the Elysian Fields has a pronounced comic tone in places, it must be said that it differs from the traditional form insofar as Wolfe and Montcalm might actually have had a conversation during their lifetimes. However, the same might be said of some of those Lyttleton's collection, which begins with a pair of exchanges on military subjects. The first is a conversation between a couple of seventeenth century figures, Lord Falkland and Mr. Hampden, on the English Civil War. The second one features an exchange between "Louis Le Grand" and "Peter the Great" of Russia, whose reigns, of course, did overlap. The Sun King mocks his Russian counterpart for working as a shipwright, but Peter clearly outscores his rival by the end of the dialogue. (Comparisons of these European monarchs were a standard and popular topic, and one senses the influence of Lyttelton's friend Fielding who had mocked the designation of "greatness" in his history of Jonathan Wild and elsewhere.) In any case, the Dialogue betwixt Wolfe and Montcalm, unlike Lyttelton's, is centered around a very specific and contemporary event - namely the fall of Quebec. McNairn believes it to have been published in November 1759. Despite this difference - the greater temporal immediacy of the anonymous Wolfe/Montcalm dialogue - the styles of all these texts are so similar that one could almost suspect Lyttelton to be the author of the Wolfe/Montcalm piece, though this seems unlikely, for one would assume that he would have included it in his collection.

The Dialogue betwixt Wolfe and Montcalm begins with Montcalm obsequiously acknowledging his adversary's glory in capturing not only Quebec but Louisbourg as well. A characteristic of the dialogue of the dead is that the dead seem to be all the more petty and fallible for being dead. The French general admits to feeling "envy" about Wolfe's exalted position. ${ }^{10}$ Wolfe responds with equal graciousness. We could be listening to the mock civilities supposedly exchanged between the French and English officers just before the commencement of the artillery bombardment at the beginning of the battle of Fontenoy - you fire first; thanks for the offer but no, you fire first. Wolfe hints at the reason for their different legacies - that Montcalm's troops simply did not serve

10 A Dialogue betwixt General Wolfe and the Marquis Montcalm, London [and Coventry]: 1759. 3. Hereafter cited as Dialogue betwixt Wolfe and Montcalm. 
well: "if success has not attended your courage, and your prudence, it is because the head who projects, cannot execute without arms". Montcalm immediately takes up this theme and runs with it. The English soldiers were "intrepid ... against the mouth of the cannon"; unlike the French who acted like "puppets, who lose their activity and motion as soon as the least spring is broke". ${ }^{11}$ If the French were insufficiently prepared, then it was due to a lack of support from the home country: "Methinks the French Monarch is govern'd by a company of Commedians! [sic]". ${ }^{12}$ Montcalm concludes by claiming that his mission was handicapped by having to immediately redress the incompetence of "Dieskow" [Dieskau]. Montcalm's strategy is to excuse his lack of accomplishment by complaining about the mess he inherited.

Wolfe responds by launching into his own praise of the English Minister, unnamed, but whom the reader will immediately know as William Pitt, who has marshaled not only a formidable land force but a powerful navy as well. At this point, the exchange stalls for a bit. Montcalm repeats his envy at the glorious reputation Wolfe has earned in subsequent history and refers disparagingly to his own sacrifice as an "act of despair". ${ }^{13}$ Then, Montcalm makes a sweeping denunciation of the French: "you who design'd to subdue the Universe, are become the contempt and ignominy of mankind". ${ }^{14}$ The second person "you" marks Montcalm as an entity no longer aligned with his nation of origin. To this point there is really nothing particularly noteworthy about the dialogue; it seems more like British propaganda rather than an entertaining clash of ideas.

Next, the reader is subjected to a history lesson from Wolfe on the French strategy to defeat the English in America. Reference is made to France's repeated violations "of the $15^{\text {th }}$ article of the treaty of Utrecht," which has to do with France and Great Britain refraining from any attempt to use the indigenous people of America against the settlement or trade of each other. ${ }^{15}$ That both colonial powers probably violated the article is overlooked, apparently willfully. At times military dialogues will contain outrageous claims that expose the speaker as either vain

11 Dialogue betwixt Wolfe and Montcalm, 4.

12 Dialogue betwixt Wolfe and Montcalm , 5.

13 Dialogue betwixt Wolfe and Montcalm , 6.

14 Dialogue betwixt Wolfe and Montcalm, 6-7.

15 Chalmers, George. A Collection of Treaties Between Great Britain and Other Powers. London: 1790. Vol. 1, 382. 
or boastful - the braggart soldier essentially — but here Wolfe's version of history seems to be accepted as accurate. At least there is no exposure of it as questionable, which has prompted Keener to suggest that the historical content of the piece is suspect. A good portion of the commentary has to do with British activity, or lack thereof, in Nova Scotia. Wolfe then generalizes with the observation that Great Britain has been neglectful of ensuring that France adhere to the Treaty. Wolfe simply asserts "the French have been always the aggressors in that part of the world" ${ }^{16}$ He then admits that a majority of natives sided with the French, a fact that resulted in a lack of resources being put into the regular French military resources. Montcalm concurs with Wolfe's version of history and emphasizes France's failure to support its American colonies with the requisite naval and land forces. No attempt is made to justify the French restraint from colonial incursion, in favor of trade, when compared to the much greater influx of settlers in the English colonies down the eastern seaboard. Such counterarguments normally mark the traditional military dialogue. So rather than an intellectual polemic, this part of the dialogue reads like undisguised British propaganda.

Wolfe moves on to another topic by suggesting that France's ambitions on the European continent diverted resources from America and led to the loss of New France, and Montcalm himself introduces a new topic by admitting that France has failed to provide basic food staples for its citizens. ${ }^{17}$ Wolfe claims to have been amused by the French King's decision to strike against English trade (read shipping) without having the muscle to back it up, and he then asks Montcalm a direct question - how did he obtain his command? Montcalm begins his answer by referring to "Dieskaw" [Dieskau], defeated at Lake George in 1755 - and imprisoned but recommended to the command of the French forces in America by the "late Marschal of Saxe."18 As for himself, Montcalm claims to have fled Versailles and presumably any attempts to ingratiate himself with the court or with those who could have assisted him with an important posting. He maintains that his command was obtained with a direct request. The implication is that the French court forgot about New France until it was too late to save it.

17 See Dialogue betwixt Wolfe and Montcalm, 10-11. 
Wolfe then looks to the next possible threat, namely the Spanish. After a final reiteration from Montcalm about the importance of the English navy in keeping the American colonies, Wolfe shifts the tone of the dialogue completely by implying that they have both been too concerned about the living, that if he were to have the opportunity to do it again, he "would [rather] be a great coward" and enjoy the individual pleasures of human life as opposed to making the greatest sacrifice. Anyone familiar with the genre will recognize the philosophical reflection, the second-guess regarding nationalistic commitment. Wolfe starts to voice the anti-war, anti-soldier sentiments that have been a part of the genre going back to Lucian. We are suddenly pitched beyond the political sphere of European imperialism and conquest in the eighteenth century. Consider his following comments on both the French and English forces:

What fools have we been, to inlist [sic] ourselves amongst those privileged highwaymen, who desert their native country, leave their wives, children, friends and relations, renounce all the pleasures and sweets of life, in order to pursue with fury, and destroy their brethren the Europeans, in the remotest parts of the globe! $!^{19}$

Wolfe is just getting warmed up. He suggests that the Europeans may well be driven away from the continent after a century or two. After acknowledging the likely encomiums to come (the narratives, the monuments, etc.), he maintains that he would trade it all for "the company of a pretty girl ... [and] some bottles of your French wine", ${ }^{20}$ a line that McNairn mocks as not at all like Wolfe the"francophobe" ${ }^{21}$ It does fit with the subsequent image of Wolfe's reciting Gray's Elegy in a Country Churchyard in the landing-boat and expressing his sentiment that he would rather have been the author of that poem than the conqueror of Quebec. This story is rejected by most scholars who find it very unlikely that Wolfe would have violated his own command about maintaining absolute silence in the landing crafts.

Nevertheless, the Montcalm of this dialogue agrees with Wolfe and wishes that he and his own Monarch could exchange places, a thought that spawns the notion "I should do his duty with Madam

20 Dialogue betwixt Wolfe and Montcalm, 18.

21 McNairn, 5. 
Pompadour".22 This is farce, the normal register for such dialogues. Wolfe then introduces Montcalm to General Braddock and Lord Howe and points to several other officers who have made their arrival in the Elysian fields. He mentions that they all feed on "Ambrosia," which he declares he will not enjoy as much as the "food and liquors above". ${ }^{23}$ And so the dialogue closes on a final note that extols known earthly pleasure. This ending which pulls the text back to the comic and philosophical aspects of the traditional dialogue risks offending readers who in late 1759 would still have Wolfe's death fresh in their minds. This is what makes the text a little odd. In a sense the dialogue follows the Lucianic form closely, and in other aspects, it is a little too immediate and political, the loss of Wolfe too close to be considered contemplatively.

It is possible the dialogue was written by an eminent person, such as Lord Chesterfield or Horace Walpole, who would have had an interest in remaining anonymous for such a low, farcical publication (the dialogue sold for six pence). Again it may have been Lyttelton, but, as Keener points out ${ }^{24}$ he had a falling out with Pitt and so it is difficult to see him singing Pitt's praises as Wolfe does in the dialogue. In fact, it is argued that Lyttelton did just the opposite in his Dialogues with the character of Pericles whose negative depiction is supposed to represent Pitt. ${ }^{25}$ Another possibility is that the dialogue was written by the "wicked" Lord Lyttelton, George's son Thomas, who according to Keener, wanted to ridicule his father and Mrs. Montagu with his own version of the genre. ${ }^{26}$ However, all we have is a listing of his dialogues which includes one between Epaminondas and Wolfe. Joseph Grove may have been the author, but this seems doubtful. Although he published a pair of dialogues in 1761 (involving Cardinals Wosley and Ximenes), this was with a different bookseller (J. Burd). ${ }^{27}$ His tribute to Wolfe ("Letter to a Right Honourable Patriot") does contain a dramatic scene but lacks Lucianic comedy, and neither work was published anonymously. ${ }^{28}$ Fur-

Dialogue betwixt Wolfe and Montcalm, 18.

Dialogue betwixt Wolfe and Montcalm, 20.

Keener, 78.

Keener, 106.

Keener, 79 .

27 Joseph Grove, "Two Dialogues in the Elysian Fields ... Cardinal Wolsey and Cardinal Ximenes." London: 1761. . "A Letter to a Right Honourable Patriot ... " London: 1759. 
ther searches might reveal a possible author who shared a similar view of the French violations of article 15 of the Treaty of Utrecht or of the behavior of the so-called "neutral" French in Nova Scotia.

The second dialogue on the fall of Quebec, by the Chevalier de Johnstone, was only brought to light when the Chevalier's memoirs were translated in full in the nineteenth century. Like the first Wolfe/Montcalm dialogue, it differs from the classic form by virtue of the fact that its author is involved in the historical episode that is discussed, and like the first, the text ironically claims or implies an impartiality while being openly bias. Johnstone's dialogue might be summed up thus: Wolfe must be the most decorated, incompetent and fortunate general to have ever been involved in a military event; conversely, Montcalm must be the least decorated, the most competent and the most unfortunate general. Johnstone's text is much longer that the first Wolfe/ Montcalm dialogue, and large stretches of it read like a straightforward history as told from a French perspective.

The reaction among the English public to Wolfe's victory is Johnstone's first point of contention. The memorial in Westminister Abbey is represented as gross and vacuous so Johnstone deems it best to have the opinion expressed by the departed Wolfe himself: "I do not see in this mausoleum but a proof of a foolish weakness in men; what avails this block of marble to my actual state?"29 Johnstone has Wolfe go on to say that respect from those who understand what really happened at the siege of Quebec is what counts the most, and on this score Montcalm ranks high. However, Montcalm returns at the end of the dialogue to the subject of reputation, specifically the status conferred on one's memory in posterity with the comment that he has been considered "a giddy goose and ignoramus". ${ }^{30}$ The voice of Johnstone seems to be channeled through Montcalm who suggests that had he lived he would have exposed the corruption in the management of the colony and protected his own reputation from those who have spread "injurious stories, all these atrocious calumnies" about him. ${ }^{31}$

29 Chavalier de Johnstone, "Dialogue of the Dead Between M. the Marquis of Montcalm ... and M. Wolfe; or an Impartial and Military Examination of that Campaign, to Serve as a Justification of the M. the Marquis of Montcalm," in Memoirs, vol. 2., trans. and edited by Charles Winchester (Aberdeen: D. Wyllie \& Son, 1871), 5. Hereafter referred to as Impartial and Military Examination. 
As for the siege itself, Johnstone is rather critical of a number of French officers who interfered with Montcalm or prevented him from exercising his sound and decisive judgment regarding military matters. The first point concerns the lack of French artillery to oppose the British fleet as it nears Québec - guns should have been in place opposite the "Isle at Condre" at the eastern end of the Isle of Orleans. ${ }^{32}$ They were not because Montcalm "did not command a chief who was capable of executing it". ${ }^{33}$

We are also entertained with a catalog of errors by Wolfe, the first of which is dividing his troops into three camps - "Point Levis, another upon the Isle of Orleans, and the third at the Fall of Montmorency" separated by the two streams of the St Lawrence itself - rather than concentrating them in one spot and thus inviting the enemy to attack. ${ }^{34}$ The second error is the attack at Montmorency on July 31.

The observation about Wolfe's separating his army into three camps and thus making them vulnerable prompts the question why the French didn't take the initiative aggressively at this juncture. When Major Dumas did take 500 men and crossed the St. Lawrence to attack Levis, the company panicked and beat a hasty retreat. ${ }^{35}$ Another French blunder was not to engage the English at Montmorency. Since the French had knowledge of where exactly the river could be crossed, they could have launched an attack on the English camp with superior numbers. M. Levis is blamed for not being more assertive.

Just as the author of the Dialogue betwixt Wolfe and Montcalm uses the form to justify British aggression in North America, Johnstone doesn't lose the opportunity in his own version of the genre to put himself in a most favorable light. Montcalm credits the Jacobite with urging the French officers to take advantage of the native warriors allied with them, who knew the local terrain intimately. ${ }^{36}$ Accepting the native estimate of the English numbers over the fearful possibility that something close to the entire expeditionary force had somehow made its way to the banks of the Montmorency, Johnstone emerges as the sole advocate for striking the enemy in their camp as opposed to being overly cautious and reluctant to engage without approval from higher command. 
At this point in the dialogue, Johnstone challenges stereotypical generalizations of the warring nations, namely the English military's reputation for "phlegmatic bravery" as opposed to the "fiery and impetuous" mindset of the French, ${ }^{37}$ by having Montcalm draw attention to a difference in the behavior of the parties. Wolfe's offensive at Montmorency seems in fact an instance of the opposite; it is the English who acted precipitously and without "taking an exact reconnaissance" of the acclivity of the ground or exact positions of the entrenchments, while the French exercised more "sang froid" or "circumspection" under pressure enduring the substantial bombardment from the land batteries and English ships. ${ }^{38}$ This observation is really a transition to a passage that involves more substantial history in the French and Indian War. In order to establish a sense of Montcalm's superior military acumen visa-vis the English, Johnstone includes descriptions of previous battles in the conflict. Hence the reader is given summaries of the defense of Fort Carillon ("Tinoneroga" [sic] or Ticonderoga to the English) in the spring of 1758 and the defeat of Braddock in 1755. ${ }^{39}$

The first might well be characterized as Montcalm's highest achievement in the conflict. Out-numbered five to one, Montcalm finds a way to exact great losses among the English besiegers. Foreshadowing Wolfe's assault at Montmorency, Abercrombie attacks "with an inconceivable blindness and audacity" ${ }^{40}$ Wolfe, who meanwhile would have been in the middle of his own successful siege of Louisbourg, then describes the boost that Montcalm's reputation received in England after the events at Ticonderoga were known. This isn't as far-fetched as it seems; Wolfe would certainly have heard this engagement discussed back in England during the winter of 1758-59. In any case, Johnstone exaggerates the respect Wolfe might have had for the French commander in the response he makes to Montcalm's narrative of the events: "I confess to you, Sir, that the idea of having to fight against a general of your merit, made me act with trembling during the campaign of $17599^{\prime 4}{ }^{41}$ Of course,

Impartial and Military Examination, 19.

Impartial and Military Examination, 19.

39 Braddock's defeat just south of Fort Duquesne (Now Pittsburgh) is erroneously identified in Johnstone's map as having occurred in 1757 rather than 1755 (Impartial and Military Examination, map insert between pp. 24 and 25). The Monongahela is referred to as "Belle Rivière" (Impartial and Military Examination, 25). 
Johnstone's purpose is to bolster the image of the French Marquis, not create credible characterizations of these historical personages.

Braddock's defeat is just a way for Johnstone to raise the subject of how military tactics differ in Canada from those practiced in Europe. The French rely on Canadian auxiliaries or French colonists and their native allies who prefer to shoot from cover rather than engage in the open. This ability to adapt to the local terrain and practices is a definite advantage for the French as was evidenced when Braddock marched to Pittsburgh in 1755 with all his wagons of packed equipment and was vulnerable to attack along the way. Because Braddock himself was shot dead, nobody profited from this lesson back in England. Johnstone then has Wolfe speak rather eloquently on how posterity has treated Montcalm: "The dead are always in the wrong, and find few advocates sufficiently disinterested to plead their cause" ${ }^{42}$ While intended to defend the Marquis, the pronouncement actually works to give the character of Wolfe a sense of fairness and mature acuity.

The length of the individual speeches in Johnstone's Impartial and Military Examination are noticeably longer than one finds in the traditionally genre. This difference lessens the sense of an exchange of ideas but allows for more development of individual positions. However, the justifications and explanations do become a little repetitive. Montcalm characterizes the bold climb up the cliff at the Foulon cove as "a rashness beyond imagination". ${ }^{43}$ That the British force was successful in climbing up to the Plains of Abraham is, according to Montcalm, a result of extraordinarily good fortune. Wolfe responds at length, giving his views on the importance of close cooperation between the naval and land forces, and his luck in making two fortuitous discoveries: that the guard at Anse au Foulon was weak and that there were some provision crafts due to arrive from up river that night. He compares his readiness to seize the initiative on this occasion with his success at Louisbourg the year before: "Scarcely ever do surprises, well planned and executed, fail to be successful". ${ }^{44}$ This comment seems to contradict the earlier implication that Wolfe was too rash, but of course this kind of dialectical progression is at the heart of the dialogue form.

One senses that the reason for the extended length of Johnstone's text is that Johnstone himself is anxious to record his version of events 
in detail. The work may be fiction, but it is also Johnstone's own lifehistory, and Johnstone gives himself a rather large role in the justification for Montcalm's behavior during the final days of the siege. Montcalm's last speech in Johnstone's text runs over ten pages, and so the dialogue form really falls by the wayside. It is a blow-by-blow exoneration of the French commander. Johnstone had suspected that Wolfe was up to something upriver and he recommended that Montrueil be sent with the Guyenne regiment to the Plains of Abraham; something that Montcalm then claims to have ordered in writing on September 11. Meanwhile, Bougainville was supposed to be following Wolfe's troop movements along the river. Johnstone was in Montcalm's company the night of September 12, and he noted how the general was worried about the provisions that Bougainville was supposed to have sent. After having tea with Johnstone the following morning, Montcalm rode to Vaudreuil's house to learn why the battery of Samos had fired the night before, and it was then that he became aware of the British forces now assembled on the Plains. Again, Johnstone puts himself in the middle of the action, which in fact he was. At Montcalm's behest, he alerted M. Poularies, the commander the force at Beauport (down river from Quebec), to bring all but 200 men with him immediately to the "height in front of Quebec". ${ }^{45}$ That M. Poularies refused to countermand a previous order from M. Montreuil to remain where he was is underscored by Johnstone as part of his strategy to defend and vindicate Montcalm. However, Montcalm here expresses for the first time a "should have" regret about his strategy. Rather than facing Wolfe's army just outside Quebec, he should have marched around the Plains and joined Bougainville's forces on the other side. Then their combined armies could have pinned the British against the city walls the next day. One assumes that Johnstone had no inkling of the rumour that Bougainville had spent the night with his cousin's wife, Madam de Vienne $^{46}$ - surely a Lucianic detail one could not pass over. However, Johnstone's text is engaging here, both as literature and history, because of the first-hand account it provides. Certain details have been challenged by other writers with access to more complete information, but there is something raw about Johnstone's account, even if it amounts to a rosy view of his own role in the drama.

46 Gordon Donaldson, Battle for a Continent: Quebec 1759 (Toronto: Double Day, 1973), 164. 
In any case, this act in the drama is drawing to a close. Montcalm realizes that he must face Wolfe on the Plains. He makes a last-ditch request for twenty-four cannon from the city, to which M. Ramsay, the King's lieutenant at Quebec, responds by saying that he can only spare three pieces. ${ }^{47}$ We all know what happens next. Johnstone gives Montcalm an opportunity for a final plea in his own behalf: "Let us conclude presently that I have little merited the blame and injustice which they have heaped upon me in public, than you the excessive honours which they have lavished on you in your country ... $"{ }^{48}$ Wolfe agrees and confesses, "I have been guilty of errors"; he closes the dialogue by citing the epitaph of the Duke of Buckingham, "'Humanum est errore et nescire [to err is human and not to know]'".99 It is assumed that everyone in the Elysian fields knows more than what is revealed in the human world. On the other hand, being in the Elysian fields does mean that one won't feel and express the pangs and desires of what it is to be alive.

Johnstone's text lacks the greater-than-life perspective that is integral to the dialogue form, but not having such a perspective is exactly what one would expect from a participant, which Johnstone was. No mention is made of anything in Montcalm's life that is non-military. Nowhere does the general express regret for not having had the opportunity to spend more time with his wife, Angélique-Louise and their six children at his chateau in Candiac, Provence. Nowhere does he express regret for not knowing which of his daughters had passed away, and Johnstone forgoes the opportunity for father and daughter to reunite in the Elysian Fields. (Donaldson describes how Bougainville returned from France with news that one of Montcalm's daughters had passed away; he didn't know which one. Montcalm suspected it was Mirète "who was like me and whom I loved very much." $)^{50}$

There is no mention of Montcalm's apparent sense of humor, evident in his dry remark on the lack of carts for work on the fortifications but not for the construction of a casemate for Bigot's mistress: "No matter how tragic the end of all this may be, one cannot help laughing" ${ }^{51}$ Of course, Johnstone did not have access to the documents that provide the raw material for such imaginings, and that is telling, for without

Impartial and Military Examination, 40.

Impartial and Military Examination, 42-43.

49

Impartial and Military Examination, 43.

Donaldson, 108.

51

Donaldson, 108. 
the greater perspective that comes with time, without the ability to step back from the impassioned subjective experience of life's trials, there is little Lucianic entertainment. The Dialogue betwixt Wolfe and Montcalm contains only glimpses of such a perspective, such as Wolfe's comment about Madame de Pompadour, whom he had met on his trip to Paris in 1751-52. That there is nothing about Gray's Elegy is understandable since that part of Wolfe's story would only emerge years later, but it is telling that there is, equally, nothing about his engagement with Katherine Lowther, which would have been known at the time.

Perhaps even more telling is that neither dialogue really ponders the "what if?" questions. Would the final result have been any different if history had followed an alternate course in the details of what happened at Québec? Idle speculation to be sure, but precisely what the dialogue form likes to indulge in. It is LaPierre's very personal history that comes closest to a true Lucianic dialogue of the dead, especially when the historian accusingly suggests to Bougainville's face (which can only be done in an imagined equivalent of the Elysian fields) that the reason he did not respond to the alarm at the Samos battery as Wolfe was scrambling up the cliff was that "you went back to bed with your cousin's wife". ${ }^{.2}$ With great satiric flair, LaPierre closes his history by dismissing Bougainville from his study, "Les Français comme les Anglais".$^{53}$ The general consensus is that history tends to make too much of the spectacle and fascination of battle and that questions of greater imperial commitment and diplomacy should rank as more pertinent. The battle of Quebec in 1759 is reversed in 1760, but the real determining action was the arrival of the first English ship, the Lowestoft, in the spring of 1760, bringing into play the superior naval capacity of Britain and the national effort exerted by Pitt's government. In a sense we have yet to have a true dialogue of the dead about this episode of Canadian history (LaPierre's text comes close) because, as the 2009 controversy over the proposed re-enacting of the Battle on the Plains of Abraham demonstrates, ${ }^{54}$ its legacy is still alive.

\section{DAVID MCNEIL}

Dalhousie University

52 LaPierre, 266.

53 LaPierre, 301.

54 In 2009 plans to stage a re-enactment of the Battle on the Plains of Abraham for the 250 anniversary were abandoned after a public outcry. 